\title{
Shell in the rectum
}

Yoji Shibaike, ${ }^{1}$ Takanobu Hirosawa, ${ }^{2}$ Taro Shimizu ${ }^{2}$

${ }^{1}$ Department of Family Medicine, Okinawa Yaeyama Hospital, Okinawa, Japan

${ }^{2}$ Department of Diagnostic and Generalist Medicine, Dokkyo Medical University, Tochigi, Japan

\section{Correspondence to} Dr Takanobu Hirosawa, t. hirosawa1983@gmail.com

Accepted 5 June 2017
CrossMark

\section{To cite: Shibaike $Y$,} Hirosawa T, Shimizu T. BMJ Case Rep Published Online First: [please include Day

Month Year]. doi:10.1136/ bcr-2017-221125

\section{DESCRIPTION}

A 67-year-old man with Down syndrome with intellectual disability presented with fever and cough. He denied abdominal pain or any change in bowel movement. His abdominal examination was unremarkable. A contrast-enhanced CT of the chest and abdomen performed for the fever work-up incidentally revealed a sharp-edged foreign body in the rectum without perforation (figure 1, online supplementary video). A colonoscopy disclosed a conch shell, $5 \mathrm{~cm}$ in length, caught in the rectum (figure 2). Further history clarified that he mistakenly swallowed the chopstick rest made with a shell at a restaurant in Ishigaki Island, Okinawa, Japan. His fever was attributed to pneumonia, and after intravenous antibiotic therapy for several days the fever remitted. He was transferred to his residential facility. He was concluded as having swallowed shell, which transferred to the rectum after his swallowing.

The rectum and the oesophagus are two main locations of foreign bodies. ${ }^{1}$ Many objects have been described as retained rectal foreign bodies. ${ }^{2}$ The gastrointestinal sequelae depend on the type of object and its location.

A clear history of foreign body ingestion may be lacking. ${ }^{1}$ There are a variety of presentations with foreign bodies: may be asymptomatic, rectal pain, bleeding, pruritus, intestinal obstruction or rectal abscess. $^{2}$

Plain X-ray and CT are useful tests to confirm the location of foreign bodies and associated

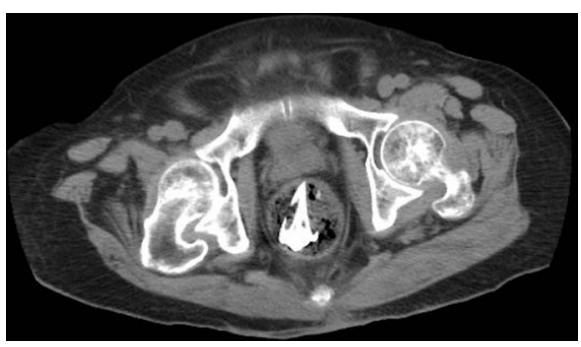

Figure 1 Pelvic CT showing a sharp-edged foreign body.

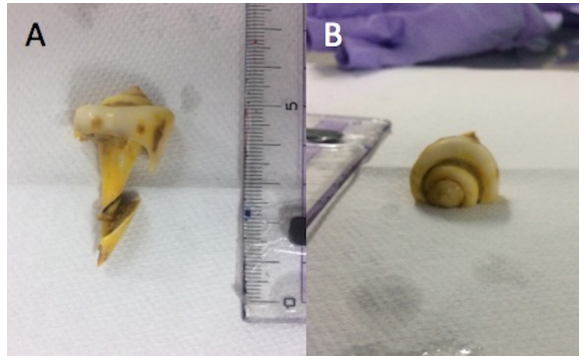

Figure $2(A, B) A$ shell in the rectum.

\section{Learning points}

- Although rare, shell can be a foreign body in digestive tract.

- Rectum and oesophagus are two main locations of foreign bodies.

- Most ingested foreign bodies that reach the stomach will pass without intervention.

complications. Fortunately, 80\%-90\% of ingested foreign objects that reach the stomach will pass without intervention. ${ }^{1}$ In clinically unstable patients with evidence of perforation or peritonitis, emergent surgery should be considered.

Contributors YS and TH were equally involved in the care of the patient. YS, TH and TS were equally involved in creation of the image and writing of the report. Written consent to publication was obtained.

Competing interests None declared.

Patient consent Obtained.

Provenance and peer review Not commissioned; externally peer reviewed.

(c) BMJ Publishing Group Ltd (unless otherwise stated in the text of the article) 2017. All rights reserved. No commercial use is permitted unless otherwise expressly granted.

\section{REFERENCES}

1 Smith MT, Wong RK. Foreign bodies. Gastrointest Endosc Clin N Am 2007;17:361-82.

2 Goldberg JE, Steele SR. Rectal foreign bodies. Surg Clin North Am 2010:90:173-84.

3 Frossard JL, de Peyer R. An unusual digestive foreign body. Case Rep Gastroenterol 2011:5:201-5. 
Copyright 2017 BMJ Publishing Group. All rights reserved. For permission to reuse any of this content visit http://group.bmj.com/group/rights-licensing/permissions.

BMJ Case Report Fellows may re-use this article for personal use and teaching without any further permission.

Become a Fellow of BMJ Case Reports today and you can:

- Submit as many cases as you like

- Enjoy fast sympathetic peer review and rapid publication of accepted articles

Access all the published articles

- Re-use any of the published material for personal use and teaching without further permission

For information on Institutional Fellowships contact consortiasales@bmjgroup.com

Visit casereports.bmj.com for more articles like this and to become a Fellow 